\title{
KEY FACTORS FOR INFORMATION INTEGRATION IN THE SUPPLY CHAIN - MEASUREMENT, TECHNOLOGY AND INFORMATION CHARACTERISTICS
}

\author{
Maciej SZYMCZAK (D)1, Urszula RYCIUK (D)2, Dorota LEOŃCZUK (D)2, \\ Wojciech PIOTROWICZ DiD 3 , Krzysztof WITKOWSKI (D) \\ Joanicjusz NAZARKO ${ }^{\mathbb{D} 2^{*}}{ }^{*}$, Joanna JAKUSZEWICZ (D) \\ ${ }^{1}$ Department of International Logistics, Faculty of International Business and Economics, \\ Poznan University of Economics and Business, Poznan, Poland \\ ${ }^{2}$ International Chinese and Central-Eastern Europe Institute of Logistics and Service Science, \\ Faculty of Engineering Management, Bialystok University of Technology, Bialystok, Poland \\ ${ }^{3}$ Department of Marketing, Supply Chain Management and Social Responsibility, \\ Hanken School of Economics, Helsinki, Finland \\ ${ }^{4}$ Department of Logistics, Faculty of Economics and Management, \\ University of Zielona Gora, Zielona Gora, Poland
}

Received 30 January 2018; accepted 03 October 2018

\begin{abstract}
This paper aims to identify key factors related to information management and integration in the supply chain. The initial set of factors was identified in the literature, namely, information quality and content, performance metrics, and information technologies. The construct was then tested empirically using the sample of 200 Polish companies. Computer-Assisted Telephone Interviews (CATI) were based on a structured questionnaire, then, data exploratory factor analysis (EFA) was performed. The conducted EFA determined four main factors for information management and integration in the supply chain that should be considered, namely, information characteristics, ICT used in information management, the scope of information and shared performance metrics. Results confirmed the importance of some of the factors related to information management in the supply chain, however having a different set of variables than indicated in the literature. Additionally, research introduced new factors, namely, information characteristics and the scope of shared information, instead of information quality and information content. Moreover, findings suggested that the key role in supply chain information integration was related to established technologies, focused on transport, customer, and ERP management, while emerging technologies, such as cloud computing and data mining were not of the top importance among the surveyed companies.
\end{abstract}

Keywords: Supply Chain Performance Management (SCPM), supply chain performance measurement, information management, information integration, information sharing technologies, Exploratory Factor Analysis (EFA).

JEL Classification: C31, C44, M15, M21.

${ }^{\star}$ Corresponding author. E-mail: j.nazarko@pb.edu.pl 


\section{Introduction}

The concept of supply chain recognises the strategic nature of cooperation between organisations that are involved in moving products and services from suppliers to end customers, typically from the initial raw materials to the ultimate consumption of finished products (Mentzer et al., 2001), and later, at the end of the product lifecycle (return, reuse and recycle). The concept has received attention from academics and practitioners since the term was coined back at the beginning of 1990s. The need for strategic thinking is of paramount importance for the supply chain to effectively compete in the market (Shapiro, 2004). One of the approaches that can be implemented in order not to keep supply-chain organisations in isolation and to maintain their performance is information sharing ( $\mathrm{Li} \& \mathrm{Lin}, 2006$, Fawcett et al., 2007a, 2007b), including information about the demand (Tan, 1999) that gained special importance due to being a prerequisite for customer service improvement across the supply chain. Integration was possible as Information and Communication Technologies (ICT) have been offering advanced data collection, processing and sharing possibilities at decreasing prices. Information is not only a binder that fills the gaps between organisations allowing the multifaceted communication but is an enabler that makes performance measurement a state-of-the-art strategic instrument. In theory, the better data is available, and the more information is precise, the more effective performance can be achieved if linked with the business strategy and operations. Therefore, consideration information characteristics including the supply-chain performance measurement and ICT are key issues explored in this paper (Lohman, Fortuin, \& Wouters, 2004).

Information management within the supply chain consists of the system for acquisition, classification, collection, processing, presentation, dissemination, and implementation of information. Information management involves the basic skills used to generate the knowledge needed to perform jobs, achieve the company's objectives on the market, support relationships, success on the market, and obtain leadership (Szuster \& Szymczak, 2016; Chodakowska \& Nazarko, 2017). Information sharing is crucial to supply-chain success, and yet it is one of the biggest areas that need constant improvement. When it comes to co-operation between organisations, many supply-chain professionals admit it is overwhelming as far as communication with those outside the organisation is involved (Jharkharia \& Shankar, 2004). Proper information management in all its extents is the basis for a much better-managed process of the flow of resources and finished goods in the supply chain, allowing supply-chain information integration. If information sharing is limited, awkward, disrupted, inefficient or information is distorted, so is the ability to manage the flows through the supply chain. This results in abnormalities in the functioning of the supply chain, such as the occurrence of the bullwhip effect, mentioning only the most known supply-chain phenomenon (Yu, Yan, \& Cheng, 2001).

Data processing in modern supply chains could be organised to follow the $3 \mathrm{~V}$ principle (visibility, velocity, versatility) in supply-chain management (Ruhi \& Turel, 2005), i.e. assure transparency, speedy action, and universality. Visibility is focused on resources in general and inventories in particular (inventory visibility). Velocity means the capacity to meet the needs (fulfilment velocity) or fulfil a contract in a short time. Versatility consists of the capacity 
to collaborate with suppliers and purchasers when faced with various terms-of-delivery (coordination versatility). These could be considered as three pillars of adaptive supply chains. Fulfilment of the $3 \mathrm{~V}$ principle requires that effective and flexible data processing models be supported by Information and Communication Technology (ICT).

Factors for Information integration were defined based on the literature, then tested based on the data from 200 manufacturing companies in Poland.

This paper is structured as follows, firstly literature on the topic is reviewed, then methodology is presented, the key part of the paper is an analysis of the factors related to information management, then the findings are discussed and compared against the literature. Finally, some conclusions and future research directions are presented.

\section{Literature review}

The literature review is separated into the sections that reflect the initial set factors, which were further analysed empirically, it means firstly information quality and content; the following two parts cover information technologies and performance measurement in the supply chain context.

\subsection{Information characteristics, quality and content}

Companies have an increasing need to deal with large volumes of data, both structured and unstructured, that floods businesses daily. Its size and characteristics make it impossible to use existing methods of analysis or available software tools for the management and processing of data. Therefore, Big Data is a current buzzword, similar to earlier concepts, such as Business Intelligence or Decision Support Systems that used to be hot topics. Big Data puts the focus on unstructured data, and the term mainly refers to the (new) methods of data analysis. However, within the concept of Big Data, a $3 \mathrm{~V}$ formula has been coined that describes characteristics of Big Data (Laney, 2001), which was then supplemented by another Vs. Now, the expanded $5 \mathrm{~V}$ formula is as follows (Hilbert, 2016):

- the volume that indicates the size of data,

- the variety that points out various formats from which data comes from (numbers, text, audio, video);

- the velocity that shows the speed of data streams;

- the variability that indicates inconsistency of data sets;

- the veracity that points out that data quality can vary greatly.

The study by Zhou and Benton Jr. (2007) considers three factors of information sharing: information quality, information content and information sharing support technology. Also, it identifies nine variables to characterise information quality: accuracy, availability, timeliness, internal connectivity, external connectivity, completeness, relevance, accessibility, and frequency of information updating (Zhou \& Benton Jr., 2007). Sharing information within the entire supply chain can create flexibility, but this requires high information quality. Information quality indicates the degree to which the information fits the company's needs (Zhou \& Benton Jr., 2007; Campo, Rubio, \& Yagüe, 2010). According to Anatan (2014), the impact of information sharing is strongly influenced by the quality of information that is 
shared and quality includes aspects such as accuracy, timeliness, adequacy, and the credibility of exchange. Such variables were also covered by other authors, including Monczka, Petersen, Handfield, and Ragatz (1998), who has introduced the concept, as well as Whipple, Frankel, and Daugherty (2002), Moberg, Cutler, Gross, and Speh (2002), Campo et al. (2010) and Li, Rao, Ragu-Nathan, and Ragu-Nathan (2005). Fynes, Voss, \& de Búrca (2005) drew attention to the following factors in information management: the quality of the communication (accuracy, timeliness, adequacy and credibility), the extent to which critical information is exchanged as well as the extent to which parties are jointly engaged in planning and goal setting. Zhou and Benton Jr. (2007) also investigated the integration of information sharing and the supply-chain practice in the supply-chain management, and their impact on the supply-chain performance, also stressing the role of information content.

Information content is the next important factor of the information management and integration in the supply chain. Li et al. (2005) described information sharing as the extent, to which critical and proprietary information is communicated to trading partners in the supply chain. It is important to share information on changing needs, core business processes, information that helps the establishment of business planning and issues that affect the business (Fiala, 2005, Lee \& Whang, 2000; Sahin \& Robinson, 2007). Information exchanged with partners can be related to some areas of the supply-chain functioning (e.g. production or delivery) or market conditions and customers (e.g. demanding forecasts). Information shared between the supply-chain partners is related to the product, the production process, resources, production order, or the planning process (Montoya-Torres \& Ortiz-Vargas, 2014). The indicators relating to information content concern two areas of information exchange:

- the extent to which important information is communicated to trading partners in the supply chain, such as information on changing needs, core business processes information that helps the establishment of business planning and issues that affect the partners business (Li et al., 2005);

- information which allows partners in the supply chain improve forecasts, synchronise production and delivery, and coordinate inventory-related decisions (Wu, Chuang, \& Hsu, 2014).

According to the literature, information sharing is composed of: information quality (including information sharing time and frequency) and information content, related to the type of information shared. The scale to measure information quality was developed based on two scales, proposed by Li et al. (2005) and Wu et al. (2014). It includes six variables: timeliness, accuracy, completeness, adequacy, reliability, and frequency of information updating. While the scale for information content includes ten variables.

However, to make information management and integration working, there is a need for tools, which allow sharing of information, ensuring information quality and the integration of the different functions and contents.

\subsection{Information technologies in a Supply Chain}

Information and Communication Technologies (ICT) are of fundamental significance for data collection, analysis, information and knowledge interchange at both organisational and supply-chain levels. ICT allows information and process integration between supply-chain 
partners. Companies that manage international flows need ICT systems, automation and electronic data interchange which enable the creation of a supply chain at the global level. The role of information technologies is focused on improving the way companies manage their supply chains. Information technology consists of the tools used to gain awareness of information, analyse this information, and act on it to increase the performance of the supply chain (Cho, Lee, Ahn, \& Hwang, 2012). ICT enables supply-chain operations especially under the conditions of globalisation, outsourcing and offshoring. A company can successfully manage the supply chain, achieving the desired effects that boost the supply-chain performance, such as short cycle times, lower inventory levels, quicker responses, better customer service. Even though information technology has costs and risks, it delivers benefits, which can be of strategic, tactical and operational levels. Some benefits are easy to measure, while other, especially strategic, can be intangible (Piotrowicz \& Irani, 2010). Data integration should be implemented within the information structure of the whole supply chain. Research indicates that the level of integration and information sharing are correlated with performance measures rather than with the supply-chain design (Sezen, 2008).

The technologies used to collect, process and share information in the supply chain include established solutions:

- communication technologies, such as e-mail, instant messaging, online chat and others used over general means of electronic communication (telecommunication networks, Internet, LANs, WANs);

- Electronic Data Interchange (EDI) systems that convert business communication on paper into electronic messages that include the same data that would normally be found on a paper document and that can be automatically interpreted and used in internal computer systems without having to make special arrangements;

- Enterprise Resource Planning (ERP) systems that incorporate the above-mentioned technologies concerning the integration of various business activities also those dispersed among many business units as these systems are now expanding into business partners.

Also, there are new emerging solutions that are applied in supply chains, allowing integration not only in the information flow but also integration between traditional and electronic commerce channels. Those include social media, mobile solutions, big data, workflow management, etc.

Thus, the next important dimension that was analysed in the survey is the use of information technologies in the supply chain. The scale was developed based on Zhou and Benton (2007). The list of technologies proposed by Zhou and Benton (2007) was extended by most recent information technologies applied in the supply chain context. Variables in the questionnaire (Appendix 1) concern the scale of the use of advanced planning and scheduling software; customer and supply relationship management systems; software used in specific processes and areas (e.g. production or warehousing); and emerging solutions to support cooperation of all partners in the supply chain (e.g. social media, cloud computing, and mobile technologies). Several technologies (such as ERP) also have a built-in function for creating the performance measurement system to define and share metrics between supplychain partners. 


\subsection{Performance measurement in supply chains}

Performance measurement enhances the decision-making in supply chains (Balfaqih, Nopiah, Saibani, \& Al-Nory, 2016); at the same time, it is challenging to design a system that involves several supply-chain partners who might have conflicting goals (Maestrini, Luzzini, Maccarrone, \& Caniato, 2017). To develop a performance measurement system (SCPMS) at the supply-chain level, a common platform should be designed to share information and coordinate processes between organisations (Maestrini et al., 2017). At the organisational level, each company might use different metrics categories, various individual metrics and definitions of each Key Performance Indicators (KPI). The latter can be based on models, such as the Balanced Scorecard, and SCOR, and integrated further to measure the supply chain. In all cases, there is a need to agree on what, when and how should be measured, how to design SCPMS, and, in the cases where the performance of an individual organisation is shared, to monitor the performance of the supply chain. Such designing includes metrics selection, data capture and analysis, presentation and usage of individual metrics (Cuthbertson \& Piotrowicz, 2011). To complicate the situation further, supply chain members have and use different strategies, goals and performance metrics (Beamon \& Balcik, 2008), so the SCPMS has to be designed jointly by business partners to measure both the supply chain and the organisational performance (Piotrowicz \& Cuthbertson, 2015). Organisations must collaborate on defining performance metrics (Ramanathan, Gunasekaran, \& Subramanian, 2011) and agree how to describe, calculate, share and use metrics at both strategic and operational levels. Moreover, there should be the alignment between the organisational strategy, the functional supplychain strategy and practices (McAdam, Hazlett, \& Galbraith, 2014).

Strategic level performance metrics. Performance measurement is related to strategic goals and intent (Morgan, 2004). To reflect this connection, there should also be a link between organisational strategy and performance metrics (Neely, Gregory, \& Platts, 1995; Piotrowicz \& Cuthbertson, 2015). In one supply chain, there might be conflicting or unaligned goals between partners, or reluctance to share sensitive information. Nevertheless, to monitor common strategic goals, performance must be aligned with strategy, and then shared between supply chain partners at strategic and operational levels.

Operational level performance metrics. There should be a clear division between metrics at each organisational level (Gunasekaran, Patel, \& Tirtiroglu, 2001), as individual managers should understand links between metrics and operations under their control (Brewer \& Speh, 2001). The implementation of the SCPMS influences operational performance at the company level (Maestrini et al., 2017) as strategy drives, but at the same time is influenced by operating standards (Morgan, 2004). Thus, to link and monitor organisational processes at the operational level, there is a need to share operational metrics.

Based on the literature in the questionnaire, three questions that reflect key constructs from the literature were included; performance metrics sharing at strategic and operational levels, and on collaborative metrics definition (Appendix 1).

When the performance measurement system is designed, information from partners should be shared and data from different sources integrated (Maestrini et al., 2017). Performance measurement systems are supported and enabled by ICT, both traditional and 
cloud-based solutions. In the SCPMS, there should be a data capture and analysis system in place, linked with the ERP, tracking, operational and analytical applications in both organisations (Cuthbertson \& Piotrowicz, 2011).

Based on the literature overviewed in the earlier sections, the research aims to identify the factors that are influencing information management and integration in the supply chain context starting from four groups of factors identified in the literature, namely

1. information quality,

2. information content,

3. performance metrics,

4. information technologies.

The research is testing empirically the importance of the initial set of factors reflected in the answers given by managers, answering the questions:

RQ1 How many and what factors should be taken into consideration in the supply-chain information management?

RQ2 What are the key variables within each of the factors?

\section{Data and research method}

The research was conducted using the CATI (computer-assisted telephone interviews) technique. Interviews were conducted with the management staff following a structured questionnaire; the work was based on the positivist paradigm. The research sample consisted of 200 Polish companies (located across Poland) employing 50 or more employees, of which $63 \%$ were medium-sized enterprises employing less than 250 employees, and $37 \%$ of large enterprises employing over 250 employees. Companies represented four sectors of the economy: automotive, food, furniture as well as consumer electronics and household appliances, which are among most advanced sectors of the Polish economy. The research sample was selected randomly using the quota sampling method (Table 1). The percentage of denials or unsuccessful contact attempts amounted to $81 \%$.

Table 1. Information according the research sample $(n=200)$ (source: elaborated by the authors)

\begin{tabular}{|l|c|c|}
\hline \multicolumn{1}{|c|}{ Sector of the economy } & Number of companies (\% n) & $\begin{array}{c}\text { Number of denials or unsuc- } \\
\text { cessful contact attempts (\% n) }\end{array}$ \\
\hline Automotive & $50(25 \%)$ & $373(44 \%)$ \\
\hline Food & $50(25 \%)$ & $140(16 \%)$ \\
\hline Furniture & $50(25 \%)$ & $152(18 \%)$ \\
\hline $\begin{array}{l}\text { Consumer electronics and } \\
\text { household appliances }\end{array}$ & $50(25 \%)$ & $192(22 \%)$ \\
\hline Total & $200(100 \%)$ & $857(100 \%)$ \\
\hline
\end{tabular}

The questionnaire consisted of 29 variables, six focused on information quality, sixteen on information content, three on performance metrics, while ten referred to the use of information technologies (see Appendix 1 for the full list). Questions were listed in the questionnaire 
separated into groups related to information and technologies, but not according to the factors. The Likert's seven-level scale was used in the questionnaire to evaluate each indicator: from "strongly disagree" to "strongly agree" in case of items related to the assessment of information and performance metrics in the supply chain. In the case of items referred to the use of information technologies, the choice was from "not used at all" to "commonly used".

To identify the structure of the data, the Exploratory Factor Analysis (EFA) was performed. The Exploratory Factor Analysis is used to statistically explore the number of factors that best fit the data. The EFA aims to obtain a minimum number of factors that contain the maximum possible amount of information contained in the original variables used in the model, having the greatest possible reliability (Rossoni, Engelbert, \& Bellegard, 2016). The use of the EFA allows the identification of a small number of latent variables (factors) that cannot be measured directly but are presented by observable indicators (Jung, 2013). Data were analysed using the IBM SPSS Statistics version 21.0.

The Kaiser-Meyer-Olkin (KMO) measure of sampling adequacy was 0.85 , indicating a good sample size. The Bartlett's test of sphericity was significant $\left(\chi^{2}(406)=2538.261\right.$, $\mathrm{p}<0.000$ ), which indicated that the variables were correlated enough for the EFA analysis, i.e. they were bigger than the suggested minimum values of 0.5 (Field, 2009) and 0.6 (Tabachnick \& Fidell, 2013). The number of factors to retain was decided using the Kaiser rule (retain factors with eigenvalues higher than 1) and scree plot analysis (Cattell's scree test). The analysis was performed using the Principal Axis Factoring and Varimax (orthogonal) rotation method. The analysis returned four factors, which explained $55.74 \%$ of the total variance. When considering the factor loadings, items with the factor loading lower than 0.50 were excluded. Typically, such loadings were notably greater than recommended 0.40 (Nunnally \& Bernstein, 1994).

The following section presents results of the EFA analysis.

\section{Factors relevant to the supply chain information management and integration}

The final rotated factor matrix for the EFA is presented in Table 2. The use of EFA enabled the identification of four factors related to information management in the supply chains, namely:

1. information characteristics,

2. ICT used in information management,

3. the scope of information shared,

4. the performance metrics shared across the supply chain.

The final set of factors differ from the initial list created based on the literature (Figure 1).

The analysis indicates that while two factors remain the same (performance metrics and information technologies), two further should be regrouped; in addition, the order of importance also changes (Figure 1). The new set of factors is as follows.

Factor 1 "Information characteristics" relates to variables emblematic of sharing information between partners in the supply chain about issues that affect the business and about 


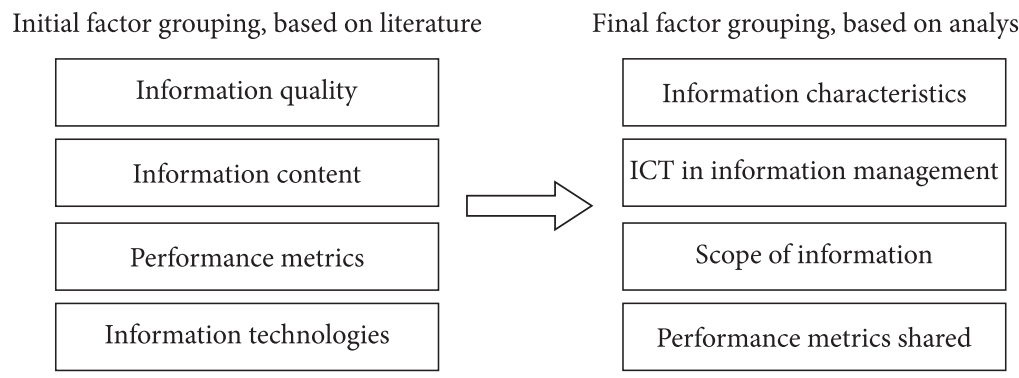

Figure 1. Key factors in information management and integration (source: elaborated by the authors)

core business processes as well as the quality of information shared, i.e. its completeness, accuracy, adequacy, reliability, timeliness and frequency of information updating.

Factor 2 includes six variables that are focused on technologies supporting information exchange and advanced planning and scheduling in the supply chain (information systems and technologies that enable collection, processing and transmission of current information) and, therefore, it was labelled "ICT used in information management". Information sharing is supported mainly by Transportation or Warehouse Management Systems (TMS and/or WMS), Customer Relationship Management systems (CRM), Advanced planning and scheduling software (including ERP), Mobile technologies, Supply Relationship Management (SRM) systems and Manufacturing Execution Systems (MES).

Factor 3 contains four variables addressing visibility of production, delivery, sale and inventory data to all partners of the supply chain. The factor was named "Scope of information shared".

Finally, Factor 4 relates to performance metrics shared across the supply chain - metrics at the operational and strategic levels defined collaboratively and shared across the supply chain. The factor was labelled "Performance metrics shared".

Table 2. Factors related to information management in supply chains. An Exploratory Factor Analysis results $(n=200)$ (source: own elaboration)

\begin{tabular}{|c|c|c|c|c|c|c|}
\hline Factor & Indicators & \multicolumn{4}{|c|}{ Factor loadings } & $\begin{array}{l}\text { Variance } \\
\text { explained }\end{array}$ \\
\hline \multirow{5}{*}{$\begin{array}{l}\text { Factor } 1 \\
\text { Informa- } \\
\text { tion cha- } \\
\text { racteristics } \\
\alpha=0.88\end{array}$} & $\begin{array}{l}\text { Information exchange between our } \\
\text { trading partners and us is complete }\end{array}$ & 0.792 & 0.093 & 0.164 & 0.042 & \multirow{5}{*}{$21.76 \%$} \\
\hline & $\begin{array}{l}\text { Information exchange between our } \\
\text { trading partners and us is accurate }\end{array}$ & 0.787 & 0.121 & 0.158 & -0.002 & \\
\hline & $\begin{array}{l}\text { Information exchange between our } \\
\text { trading partners and us is adequate }\end{array}$ & 0.787 & 0.084 & 0.181 & 0.033 & \\
\hline & $\begin{array}{l}\text { Information exchange between our } \\
\text { trading partners and us is reliable }\end{array}$ & 0.726 & 0.070 & 0.106 & 0.159 & \\
\hline & $\begin{array}{l}\text { Information exchange between our } \\
\text { trading partners and us is timely }\end{array}$ & 0.724 & 0.166 & -0.025 & 0.073 & \\
\hline
\end{tabular}


End of Table 2

\begin{tabular}{|c|c|c|c|c|c|c|}
\hline \multirow[t]{5}{*}{ Factor } & \multirow{2}{*}{$\begin{array}{l}\text { Indicators } \\
\text { Information exchanged between our } \\
\text { trading partners and us is updating } \\
\text { frequently }\end{array}$} & \multicolumn{4}{|c|}{ Factor loadings } & $\begin{array}{l}\text { Variance } \\
\text { explained }\end{array}$ \\
\hline & & 0.673 & 0.158 & 0.080 & 0.194 & \\
\hline & $\begin{array}{l}\text { Our trading partners keep us fully } \\
\text { informed about issues that affect our } \\
\text { business }\end{array}$ & 0.673 & 0.136 & 0.137 & 0.202 & \\
\hline & $\begin{array}{l}\text { Our trading partners share business } \\
\text { knowledge of core business processes } \\
\text { with us }\end{array}$ & 0.549 & 0.165 & 0.218 & 0.175 & \\
\hline & $\begin{array}{l}\text { We inform trading partners in ad- } \\
\text { vance of changing needs }\end{array}$ & 0.539 & 0.128 & 0.112 & 0.252 & \\
\hline \multirow{6}{*}{$\begin{array}{l}\text { Factor } 2 \\
\text { ICT used } \\
\text { in infor- } \\
\text { mation } \\
\text { manage- } \\
\text { ment } \\
\alpha=0.80\end{array}$} & $\begin{array}{l}\text { Transportation/warehouse Manage- } \\
\text { ment software (TMS/WMS) }\end{array}$ & 0.143 & 0.757 & 0.067 & 0.052 & \multirow{6}{*}{$12.00 \%$} \\
\hline & $\begin{array}{l}\text { Customer Relationship Management } \\
\text { systems (CRM) }\end{array}$ & 0.068 & 0.732 & 0.144 & 0.043 & \\
\hline & $\begin{array}{l}\text { Advanced planning and scheduling } \\
\text { software (including ERP) }\end{array}$ & 0.209 & 0.639 & -0.088 & 0.135 & \\
\hline & $\begin{array}{l}\text { Mobile technologies (smartphone/ } \\
\text { tablets) }\end{array}$ & 0.137 & 0.545 & 0.166 & 0.055 & \\
\hline & $\begin{array}{l}\text { Supply Relationship Management } \\
\text { systems (SRM) }\end{array}$ & 0.005 & 0.523 & 0.256 & 0.092 & \\
\hline & $\begin{array}{l}\text { Manufacturing Execution Systems } \\
\text { (MES) }\end{array}$ & 0.193 & 0.513 & -0.063 & 0.192 & \\
\hline \multirow{4}{*}{$\begin{array}{l}\text { Factor } 3 \\
\text { Scope of } \\
\text { informa- } \\
\text { tion shared } \\
\alpha=0.83\end{array}$} & $\begin{array}{l}\text { Inventory data are visible at all part- } \\
\text { ners in the supply chain }\end{array}$ & 0.168 & 0.019 & 0.764 & 0.095 & \multirow{4}{*}{$11.33 \%$} \\
\hline & $\begin{array}{l}\text { Production data are visible at all } \\
\text { partners in the supply chain }\end{array}$ & 0.187 & 0.148 & 0.747 & 0.207 & \\
\hline & $\begin{array}{l}\text { Delivery data are visible at all part- } \\
\text { ners in the supply chain }\end{array}$ & 0.151 & 0.113 & 0.667 & 0.158 & \\
\hline & $\begin{array}{l}\text { Actual sale data are visible at all } \\
\text { partners in the supply chain }\end{array}$ & 0.146 & 0.110 & 0.656 & 0.152 & \\
\hline \multirow{3}{*}{$\begin{array}{l}\text { Factor } 4 \\
\text { Perfor- } \\
\text { mance } \\
\text { metrics } \\
\text { shared } \\
\alpha=0.91\end{array}$} & $\begin{array}{l}\text { Performance metrics are shared } \\
\text { across the supply chain (at strategic } \\
\text { level) }\end{array}$ & 0.231 & 0.154 & 0.249 & 0.881 & \multirow{3}{*}{$10.64 \%$} \\
\hline & $\begin{array}{l}\text { Performance metrics are shared } \\
\text { across the supply chain (at opera- } \\
\text { tional level) }\end{array}$ & 0.239 & 0.208 & 0.232 & 0.809 & \\
\hline & $\begin{array}{l}\text { Supply chain partners collaborate in } \\
\text { defining performance metrics }\end{array}$ & 0.179 & 0.159 & 0.218 & 0.730 & \\
\hline
\end{tabular}

The reliability analysis for each extracted factor (measurement scale) was made using the Cronbach's alpha. In all cases, the Cronbach's alpha was higher than 0.60 - the Cronbach's alphas were $0.88,0.80,0.83$ and 0.91 for Factors 1, 2, 3 and 4, respectively. The Cronbach's alpha was greater than 0.6 , especially with a small number of questions, which means that 
the set of observable variables (measured directly on the Likert scale) is a reliable instrument for latent variable measurement. All the developed scales demonstrated reliabilities above the recommended threshold range of 0.6-0.7 (Nunnally \& Bernstein, 1994).

\section{Discussion}

The use of the EFA enabled the identification of four factors (Table 2) related to information management in supply chains, answering the Research Question 1 as well as key variables within each factor (answering RQ2).

Factor 1 "Information characteristics" is composed of two aspects of information flow across the supply chain indicated by Li et al. (2005): the level of information quality and the level of information sharing. In the article by $\mathrm{Li}$ et al., these are two separate aspects of the supply chain management practice undertaken in an organisation to promote effective management. Information quality relates to such elements as timeliness, accuracy, completeness, adequacy, and reliability. Information sharing relates to the extent to which critical information (on changing needs, core business processes, information that helps the establishment of business planning and issues that affect the business) is communicated in the supply chain. The developed single factor is consistent with the suggestion of the authors that information sharing, and information quality can be combined into information management (Li et al., 2005). Thus, it is hard to separate quality from the type of information.

Factor 2 "ICT used in information management" was introduced based on the analysis. It was formed from the extension of the proposal formulated by Zhou and Benton (2007) who defined information sharing as "Information quality", "Information content" and "Information sharing support technology" that focuses on the advanced manufacturing technology and emerging supply chain management ICT applications supporting warehouse management, transportation management or supply chain execution management. According to the results of the conducted Exploratory Factor Analysis, Factor 2 included six items that focused on technologies supporting information exchange and advanced planning and scheduling in the supply chain: TMS and/or WMS, CRM, advanced planning and scheduling software (including ERP), mobile technologies, SRM and MES. Nevertheless, the results of research show new technologies and possibilities of data exchange, such as Groupware and Workflow Management Software. Social Media Data Mining and Big Data, were excluded; consequently, they were still not very popular between supply chains partners as key technologies.

Factors 3 and 4 were based on the proposal initially formulated by Wu et al. (2014). Authors used "information sharing" to describe the factor which took into consideration such issues as:

1. Inventory data are visible to all partners in the supply chain.

2. Production and delivery data are shared across the supply chain.

3. Actual sale data are visible at all partners in the supply chain.

4. Demanding forecasts are shared across the supply chain.

5. Performance metrics are shared across the supply chain.

Research results show that this factor can be divided into two factors named "Scope of information shared" that is associated with visibility of production, delivery, sale and inventory 
data to all partners in the supply chain; and "Performance metrics shared" that contains items related to the exchange of information on performance metrics - the identification of this factor emphasises the importance of collaboratively defining performance metrics and sharing them at the operational and strategic levels.

The four factors identified as a result of the analysis are:

1. Information characteristics,

2. ICT used in information management,

3. The scope of information shared,

4. Performance metrics shared across the supply chain.

Such four factors are related to information management, which at the same time are consistent with the information visibility, one of the key factors listed as important in the supply-chain context. Visibility is the first pillar of the $3 \mathrm{~V}$ formula by Ruhi and Turel (2005).

\section{Conclusions}

The dynamic progress of technologies facilitating the accumulation, processing and transfer of data allows transformation of traditional supply chains into extensive supply networks characterised by complex interactions between organisations. The achieved performance and competitiveness of supply chains largely depend on common planning, problem-solving, and information sharing. Proper information management is the basis for a proper process of the flow of resources and goods in a supply chain. If information sharing is limited, disrupted or inefficient ability to manage the flow through the supply chain is much lower.

The theoretical contribution is related to testing a literature-based model using empirical data from four sectors. As a result, the construct of the factors was modified. According to the conducted Exploratory Factor Analysis, four main factors should be considered in data management and integration of supply chains, namely, information characteristics, ICT used in information management, the scope of information shared, and performance metrics shared across the supply chain. Factors relate to basic elements in sharing information between supply chain partners: information completeness, information accuracy, information adequacy, information reliability, information timeliness and frequency of information; hence, updating and the basic scope of information shared, i.e. the visibility of production, the delivery, sale and inventory data, to all partners in the supply chain. Information exchange should be supported by information systems and technologies (ICT) that enable the collection, processing and transmission of information. Information management is essential for the decision-making in supply chains; so, the last factor relates to performance metrics at the operational and strategic levels shared across the supply chain. Four identified factors related to information management are consistent with the first requirement of the $3 \mathrm{~V}$ formula, i.e. are related to visibility focused on resources. However, further work is required to identify ways the visibility influences the velocity and versatility, meaning the inventory management and cooperation with suppliers. The results of the factor analysis will be used in the future to develop the structural equations model. The research is a part of an ongoing focus on the important investigations on the development and evolution of supply chains: 
the Supply Chain Performance Measurement evidently supports the process of continuous improvement and increased efficiency. Further work should test the factors using data from different sectors and regions, allowing comparative studies. Qualitative research of both single and multiple case studies will allow a deeper understanding of how, when and about what information is exchanged as well as to understand more about the process of metrics selection and definition.

Besides, research has practical implications. Firstly, the quality of data is related to the content; therefore, it is important to look at issues related to completeness, accuracy and other quality properties of information as well as the content of what is shared. High-quality information has little value from the business point of view just as low-quality information on important issues. When looking at the use of ICT, the results indicate that organisations should firstly focus on already established technologies, while those at an emerging stage have no key roles; however, this will likely change over time. Findings also confirm the importance of joint performance metrics, which should be jointly defined, and then shared between supply chain partners.

Research has limitations. Data were collected from four manufacturing sectors of Poland (automotive, food, furniture, and consumer electronics), findings were limited to national and sectoral context. Another issue is related to translation, as data were collected in the Polish language, some terms might be interpreted differently by respondents. Future work should investigate companies from different countries, regions, manufacturing and service sectors. Another limitation is that the set of the factors included in the questionnaire were applied from the selected papers only. Authors have selected factors and related variables; however, some were not included. This creates an opportunity to test and modify the model, which can be extended further by testing additional factors, both identified in the literature as well as from the qualitative fieldwork.

\section{Author contributions}

M. Szymczak, D. Leonczuk, U. Ryciuk, W. Piotrowicz and J. Nazarko were responsible for the study conception and design. U. Ryciuk performed statistical analysis. U. Ryciuk, M. Szymczak and D. Leonczuk were responsible for data interpretation. M. Szymczak, U. Ryciuk, D. Leonczuk, J. Nazarko, W. Piotrowicz, K. Witkowski and J. Jakuszewicz discussed the results and contributed to the final manuscript.

\section{Funding}

This work was supported by the National Science Centre, Poland under Grant no. 2014/13/B/ HS4/03293.

\section{Disclosure statement}

Authors declare that they have no competing financial, professional, or personal interests from other parties. 


\section{References}

Anatan, L. (2014). Factors influencing Supply Chain competitive advantage and performance. International Journal of Business and Information, 9(3), 311-334.

Balfaqih, H., Nopiah, Z. M., Saibani, N., \& Al-Nory, M. T. (2016). Review of supply chain performance measurement systems: 1998-2015. Computers in Industry, 82, 135-150. https://doi.org/10.1016/j.compind.2016.07.002

Beamon, B. M., \& Balcik, B. (2008). Performance measurement in humanitarian relief chains. International Journal of Public Sector Management, 21(1), 4-25. https://doi.org/10.1108/09513550810846087

Brewer, P. C., \& Speh, T. W. (2001). Adapting the balanced scorecard to supply chain management. Supply Chain Management Review, 5(2), 48-56.

Campo, S., Rubio, N., \& Yagüe, M. J. (2010). Information technology use and firm's perceived performance in Supply Chain management. Journal of Business-to-Business Marketing, 17(4), 336-364. https://doi.org/10.1080/10517120903574649

Cho, D. W., Lee, Y. H., Ahn, S. H., \& Hwang, M. K. (2012). A framework for measuring the performance of service supply chain management, Computers \& Industrial Engineering, 62(3), 801-818. https://doi.org/10.1016/j.cie.2011.11.014

Chodakowska E., \& Nazarko J. (2017). Network DEA Models for Evaluating Couriers and Messengers. Procedia Engineering, 182, 106-111. https://doi.org/10.1016/j.proeng.2017.03.130

Cuthbertson, R., \& Piotrowicz, W. (2011). Performance measurement systems in supply chains: a framework for contextual analysis. International Journal of Productivity and Performance Management, 60(6), 583-602. https://doi.org/10.1108/17410401111150760

Fawcett, S. E., Ellram, L. M., \& Ogden, J. A. (2007a). Supply chain management. From vision to implementation. Upper Saddle River, NJ: Pearson Education.

Fawcett, S. E., Osterhaus, P., Magnan, G. M., Brau, J. C., \& McCarter, M. W. (2007b). Information sharing and supply chain performance: the role of connectivity and willingness. Supply Chain Management: An International Journal, 12(5), 358-368. https://doi.org/10.1016/j.sbspro.2015.01.1225

Fiala, P. (2005). Information sharing in supply chains. Omega, 33(5), 419-423. https://doi.org/10.1016/j.omega.2004.07.006

Field, A. (2009). Discovering statistics using SPSS. London: SAGE Publications.

Fynes, B., Voss, C., \& de Búrca S. (2005). The impact of supply chain relationship quality on quality performance. International Journal of Production Economics, 96(3), 339-354. https://doi.org/10.1016/j.ijpe.2004.05.008

Gunasekaran, A., Patel, C., \& Tirtiroglu, E. (2001). Performance measures and metrics in a supply chain environment. International Journal of Operations \& Production Management, 21(1/2), 71-87. https://doi.org/10.1108/01443570110358468

Hilbert, M. (2016). Big Data for development: a review of promises and challenges. Development Policy Review, 34(1), 135-174. https://doi.org/10.1111/dpr.12142

Jharkharia, S., \& Shankar, R. (2004). IT enablement of supply chains: modelling the enablers. International Journal of Productivity and Performance Management, 53(8), 700-712. https://doi.org/10.1108/17410400410569116

Jung, S. (2013). Exploratory factor analysis with small sample sizes: a comparison of three approaches. Behavioural Processes, 97, 90-95. https://doi.org/10.1016/j.beproc.2012.11.016

Laney, D. (2001). 3D data management: controlling data volume, velocity and variety, application delivery strategies, META Group Inc. Retrieved from https://blogs.gartner.com/doug-laney/ files/2012/01/ad949-3D-Data-Management-Controlling-DataVolume-Velocity-and-Variety.pdf 
Lee, H. L., \& Whang, S. (2000). Information sharing in a supply chain. International Journal of Manufacturing Technology and Management, 1(1), 79-93. https://doi.org/10.1504/IJMTM.2000.001329

Li, S., \& Lin, B. (2006). Accessing Information sharing and information quality in supply chain management. Decision Support Systems, 42, 1641-1656. https://doi.org/10.1016/j.dss.2006.02.011

Li, S., Ragu-Nathan, B., Ragu-Nathan, T. S., \& Rao, S. S. (2006). The impact of supply chain management practices on competitive advantage and organizational performance. The International Journal of Management Science, 34(2), 107-124. https://doi.org/10.1016/j.omega.2004.08.002

Li, S., Rao, S. S., Ragu-Nathan, T. S., \& Ragu-Nathan, B. (2005). Development and validation of a measurement instrument for studying chain management practices. Journal of Operations Management, 23(6), 618-641. https://doi.org/10.1016/j.jom.2005.01.002

Lohman, C., Fortuin, L., \& Wouters, M. (2004). Designing a performance measurement system: a case study. European Journal of Operations Research, 156(2), 267-286.

https://doi.org/10.1016/S0377-2217(02)00918-9

Maestrini, V., Luzzini, D., Maccarrone, P., \& Caniato, F. (2017). Supply chain performance measurement systems: a systematic review and research agenda. International Journal of Production Economics, 183, 299-315. https://doi.org/10.1016/j.ijpe.2016.11.005

McAdam, R., Hazlett, S. A., \& Galbraith, B. (2014). The role of performance measurement models in multi level alignment: an exploratory case analysis in the utilities sector. International Journal of Operations \& Production Management, 34(9), 1153-1183. https://doi.org/10.1108/IJOPM-09-2011-0313

Mentzer, J. T., DeWitt, W., Keebler, J. S., Min, S., Nix, N. W., Smith, C. D., \& Zacharia Z. G. (2001). Defining supply chain management. Journal of Business Logistics, 22(2), 1-25. https://doi.org/10.1002/j.2158-1592.2001.tb00001.x

Moberg, C. R., Cutler, B. D., Gross, A., Speh, T. W. (2002). Identifying antecedents of information exchange within supply chains. International Journal of Physical Distribution \& Logistics Management, 32(9), 755-770. https://doi.org/10.1108/09600030210452431

Monczka, R. M., Petersen, K. J., Handfield, R. B., \& Ragatz, G. L. (1998). Success factors in strategic supplier alliances: the buying company perspective. Decision Sciences, 29, 553-577.

https://doi.org/10.1111/j.1540-5915.1998.tb01354.x

Montoya-Torres, J. R., \& Ortiz-Vargas, D. A. (2014). Collaboration and information sharing in dyadic supply chains: a literature review over the period 2000-2012. Estudios Gerenciales, 30, 343-354. https://doi.org/10.1016/j.estger.2014.05.006

Morgan, C. (2004). Structure, speed and salience: performance measurement in the supply chain. Business Process Management Journal, 10(5), 522-536. https://doi.org/10.1108/14637150410559207

Neely, A., Gregory, M., \& Platts, K. (1995). Performance measurement system design: a literature review and research agenda. International Journal of Operations \& Production Management, 15(4), 80-116. https://doi.org/10.1108/01443579510083622

Nunnally, J. C., \& Bernstein, I. H. (1994). Psychometric theory. New York: McGraw-Hill.

Piotrowicz, W., \& Cuthbertson, R. (2015). Performance measurement and metrics in supply chains: an exploratory study. International Journal of Productivity and Performance Management, 64(8), 1068-1091. https://doi.org/10.1108/IJPPM-04-2014-0064

Piotrowicz, W., \& Irani, Z. (2010). Analysing B2B electronic procurement benefits: information systems perspective. Journal of Enterprise Information Management, 23(4), 559-579. https://doi.org/10.1108/17410391011061816

Ramanathan, U., Gunasekaran, A., \& Subramanian, N. (2011). Supply chain collaboration performance metrics: a conceptual framework. Benchmarking: An International Journal, 18(6), 856-872.

https://doi.org/10.1108/14635771111180734 
Rossoni, L., Engelbert, R., \& Bellegard, N. L. (2016). Normal science and its tools: reviewing the effects of factor analysis in management. Revista de Administração (RAUSP), 51(2), 198-211. https://doi.org/10.5700/rausp1234

Ruhi, U., \& Turel, O. (2005). Driving visibility, velocity and versatility: the role of mobile technologies in supply chain management. Journal of Internet Commerce, 4(3), 95-117. https://doi.org/10.1300/J179v04n03_06

Sahin, F., \& Robinson, E. P. (2007). Flow coordination and information sharing in supply chains: review, implications, and directions for future research. Decision Sciences, 33(4), 505-536. https://doi.org/10.1111/j.1540-5915.2002.tb01654.x

Sezen, B., (2008). Relative effects of design, integration and information sharing on supply chain performance. Supply Chain Management: An International Journal, 13(3), 233-240. https://doi.org/10.1108/13598540810871271

Shapiro, J. F. (2004). Challenges of strategic supply chain planning and modelling. Computers \& Chemical Engineering, 28(6-7), 855-861. https://doi.org/10.1016/j.compchemeng.2003.09.013

Simchi-Levi, D., Kaminsky, Ph., \& Simchi-Levi, E. (2003). Designing \& Managing the Supply Chain. Concepts, Strategies \& Case Studies (2nd ed.). New York: McGraw-Hill/Irwin.

Szuster, M., \& Szymczak, M. (2016). Innovation, knowledge and information management in supply chains. Economics and Management, 8(1), 26-36. https://doi.org/10.1515/emj-2016-0003

Tabachnick, B. G., \& Fidell, L. S. (2013). Using multivariate statistics. Boston: Pearson.

Tan, G. W. (1999). The impact of demand information sharing on supply chain network (Dissertation). University of Illinois at Urbana-Champaign.

Whipple, J. M., Frankel, R., \& Daugherty, P. J. (2002). Information support for alliances: performance implications, Journal of Business Logistics, 23, 67-82. https://doi.org/10.1002/j.2158-1592.2002.tb00026.x

Wu, I-L., Chuang, Ch-H., \& Hsu, Ch-H. (2014). Information sparing and collaborative behaviors in enabling supply chain performance: a social exchange perspective. International Journal of Production Economics, 148(C), 122-132. https://doi.org/10.1016/j.ijpe.2013.09.016

Yu, Z., Yan, H., \& Edwin Cheng, T. C. (2001). Benefits of information sharing with supply chain partnerships. Industrial Management \& Data Systems, 101(3), 114-121. https://doi.org/10.1108/02635570110386625

Zhou, H., \& Benton Jr., W. C. (2007). Supply chain practice and information sharing. Journal of Operations Management, 25(6), 1348-1365. https://doi.org/10.1016/j.jom.2007.01.009 


\section{APPENDIX}

Survey indicators related to information management

\begin{tabular}{|c|c|c|c|}
\hline \multicolumn{2}{|r|}{ Survey question } & Variable & Source of the scale \\
\hline \multicolumn{4}{|c|}{ Information quality } \\
\hline 1. & $\begin{array}{l}\text { Information exchange between our trading part- } \\
\text { ners and us is timely }\end{array}$ & Timeliness & (Li et al., 2005) \\
\hline 2. & $\begin{array}{l}\text { Information exchange between our trading part- } \\
\text { ners and us is accurate }\end{array}$ & Accuracy & (Li et al., 2005) \\
\hline 3. & $\begin{array}{l}\text { Information exchange between our trading part- } \\
\text { ners and us is complete }\end{array}$ & Completeness & (Li et al., 2005) \\
\hline 4. & $\begin{array}{l}\text { Information exchange between our trading part- } \\
\text { ners and us is adequate }\end{array}$ & Adequacy & (Li et al., 2005) \\
\hline 5. & $\begin{array}{l}\text { Information exchange between our trading part- } \\
\text { ners and us is reliable }\end{array}$ & Reliability & (Li et al., 2005) \\
\hline 6. & $\begin{array}{l}\text { Information exchanged between our trading part- } \\
\text { ners and us is updating frequently }\end{array}$ & $\begin{array}{l}\text { Frequency of infor- } \\
\text { mation updating }\end{array}$ & $\begin{array}{l}\text { (Zhou \& Benton, } \\
\text { 2007) }\end{array}$ \\
\hline \multicolumn{4}{|c|}{ Information content } \\
\hline 7. & $\begin{array}{l}\text { We inform trading partners in advance of chang- } \\
\text { ing needs }\end{array}$ & $\begin{array}{l}\text { Information on } \\
\text { changing needs }\end{array}$ & (Li et al., 2005) \\
\hline 8. & $\begin{array}{l}\text { Our trading partners keep us fully informed } \\
\text { about issues that affect our business }\end{array}$ & $\begin{array}{l}\text { Issues that affect the } \\
\text { business }\end{array}$ & (Li et al., 2005) \\
\hline 9. & $\begin{array}{l}\text { Our trading partners share business knowledge of } \\
\text { core business processes with us }\end{array}$ & $\begin{array}{l}\text { Knowledge of core } \\
\text { business processes }\end{array}$ & (Li et al., 2005) \\
\hline 10. & $\begin{array}{l}\text { We and our trading partners exchange informa- } \\
\text { tion that helps establishment of business planning }\end{array}$ & $\begin{array}{l}\text { Information that } \\
\text { helps establishment } \\
\text { of business plan- } \\
\text { ning }\end{array}$ & (Li et al., 2005) \\
\hline 11. & $\begin{array}{l}\text { Inventory data are visible at all partners in the } \\
\text { supply chain }\end{array}$ & Inventory data & (Wu et al., 2014) \\
\hline 12. & $\begin{array}{l}\text { Production data are visible at all partners in the } \\
\text { supply chain }\end{array}$ & Production data & (Wu et al., 2014) \\
\hline 13. & $\begin{array}{l}\text { Delivery data are visible at all partners in the } \\
\text { supply chain }\end{array}$ & Delivery data & (Wu et al., 2014) \\
\hline 14. & $\begin{array}{l}\text { Actual sale data are visible at all partners in the } \\
\text { supply chain }\end{array}$ & Actual sale data & (Wu et al., 2014) \\
\hline 15. & $\begin{array}{l}\text { Demanding forecasts are shared across the supply } \\
\text { chain }\end{array}$ & $\begin{array}{l}\text { Demanding fore- } \\
\text { casts }\end{array}$ & (Wu et al., 2014) \\
\hline 16. & $\begin{array}{l}\text { There is a high level of integration of information } \\
\text { systems in the supply chain }\end{array}$ & $\begin{array}{l}\text { Integration of infor- } \\
\text { mation systems }\end{array}$ & own \\
\hline \multicolumn{4}{|c|}{ Performance metrics } \\
\hline 17. & $\begin{array}{l}\text { Supply chain partners collaborate in defining } \\
\text { performance metrics }\end{array}$ & $\begin{array}{l}\text { Collaboration in } \\
\text { defining perfor- } \\
\text { mance metrics }\end{array}$ & $\begin{array}{l}\text { Based on (Wu et al., } \\
\text { 2014) }\end{array}$ \\
\hline
\end{tabular}




\begin{tabular}{|c|c|c|c|}
\hline \multicolumn{2}{|r|}{ Survey question } & \multirow{2}{*}{\begin{tabular}{l}
\multicolumn{1}{c}{ Variable } \\
Performance met- \\
rics shared at stra- \\
tegic level
\end{tabular}} & \multirow{2}{*}{$\begin{array}{l}\text { Source of the scale } \\
\text { Based on (Wu et al., } \\
2014)\end{array}$} \\
\hline 18. & $\begin{array}{l}\text { Performance metrics are shared across he supply } \\
\text { chain (at strategic level) }\end{array}$ & & \\
\hline 19. & $\begin{array}{l}\text { Performance metrics are shared across the supply } \\
\text { chain (at operational level) }\end{array}$ & $\begin{array}{l}\text { Performance met- } \\
\text { rics shared at op- } \\
\text { erational level }\end{array}$ & $\begin{array}{l}\text { Based on (Wu et al., } \\
\text { 2014) }\end{array}$ \\
\hline \multicolumn{4}{|c|}{ Information technologies } \\
\hline 1. & $\begin{array}{l}\text { Advanced planning and scheduling software (in- } \\
\text { cluding ERP) }\end{array}$ & $\begin{array}{l}\text { Advanced planning } \\
\text { and scheduling } \\
\text { software }\end{array}$ & $\begin{array}{l}\text { (Zhou \& Benton, } \\
\text { 2007) }\end{array}$ \\
\hline 2. & Manufacturing Execution Systems (MES) & MES & $\begin{array}{l}\text { (Zhou \& Benton, } \\
\text { 2007) }\end{array}$ \\
\hline 3. & $\begin{array}{l}\text { Transportation/warehouse Management software } \\
\text { (WMS) }\end{array}$ & WMS & $\begin{array}{l}\text { (Zhou \& Benton, } \\
\text { 2007) }\end{array}$ \\
\hline 4. & $\begin{array}{l}\text { Customer Relationship Management systems } \\
\text { (CRM) }\end{array}$ & CRM & $\begin{array}{l}\text { own based on } \\
\text { (Zhou \& Benton, } \\
\text { 2007) }\end{array}$ \\
\hline 5. & Supply Relationship Management systems (SRM) & SRM & $\begin{array}{l}\text { own based on } \\
\text { (Zhou \& Benton, } \\
\text { 2007) }\end{array}$ \\
\hline 6. & Cloud computing & Cloud computing & $\begin{array}{l}\text { own based on } \\
\text { (Zhou \& Benton, } \\
\text { 2007) }\end{array}$ \\
\hline 7. & Mobile technologies (smartphone/tablets) & Mobile technologies & $\begin{array}{l}\text { own based on } \\
\text { (Zhou \& Benton, } \\
\text { 2007) }\end{array}$ \\
\hline 8. & Groupware and Workflow Management Software & $\begin{array}{l}\text { Groupware and } \\
\text { Workflow Manage- } \\
\text { ment Software }\end{array}$ & $\begin{array}{l}\text { own based on } \\
\text { (Zhou \& Benton, } \\
\text { 2007) }\end{array}$ \\
\hline 9. & Social media & Social media & $\begin{array}{l}\text { own based on } \\
\text { (Zhou \& Benton, } \\
\text { 2007) }\end{array}$ \\
\hline 10. & Data mining and Big Data & $\begin{array}{l}\text { Data mining and } \\
\text { Big Data }\end{array}$ & $\begin{array}{l}\text { own based on } \\
\text { (Zhou \& Benton, } \\
2007)\end{array}$ \\
\hline
\end{tabular}

